\title{
Synergistic interaction of renewable nipagin and eugenol for high performance aromatic copoly(ether ester) materials
}

Keling Hu ( $\sim$ hukeling@tiangong.edu.cn )

Tiangong University

Huachao Sui

Tianjin Medical University

Dongping Zhao

Tianjin Medical University

\section{Research Article}

Keywords: DMT, gel permeation chromatograph (GPC), WXRD, FTIR, human society, PHN1

Posted Date: July 15th, 2021

DOl: https://doi.org/10.21203/rs.3.rs-706272/v1

License: (c) (i) This work is licensed under a Creative Commons Attribution 4.0 International License.

Read Full License 


\title{
Synergistic interaction of renewable nipagin and eugenol for high performance aromatic copoly(ether ester) materials
}

\author{
Keling $\mathrm{Hu}^{1}$, Huachao $\mathrm{Sui}^{2}$ \& Dongping $\mathrm{Zhao}^{2}$ \\ ${ }^{1}$ School of Materials Science and Engineering, Tiangong University, Tianjin 300387, P. R. \\ China. \\ ${ }^{2}$ School and Hospital of Stomatology, Tianjin Medical University, Tianjin 300070, P. R. China. \\ *Correspondence to hukeling@tiangong.edu.cn
}

\begin{abstract}
Naturally occurring nipagin and eugenol were used as the collaborative starting materials for poly(ether ester) materials. In this study, two series of nipagin and eugenol-derived copoly(ether ester)s, $\mathrm{PHN} 1_{1-\mathrm{x}} \mathrm{E} 1_{\mathrm{x}}$ and $\mathrm{PHN} 1_{1-\mathrm{x}} \mathrm{E} 2_{\mathrm{x}}(\mathrm{x}=0 \%, 5 \%, 10 \%, 15 \%, 20 \%)$, were prepared with renewable 1,6-hexanediol as a comonomer. The nipagin-derived component acts as the renewable surrogate of petroleum-based dimethyl terephthalate (DMT), while the eugenol-derived component acts as the cooperative property modifier of parent homopoly(ether ester) PHN1. 1,6-Hexanediol was chosen as the spacer because of its renewability and short chain to enhance the glass transition temperatures $\left(T_{\mathrm{g}} \mathrm{s}\right)$ of materials. The molecular weights and chemical structures were confirmed by gel permeation chromatograph (GPC), NMR and FTIR spectroscopies. Thermal and crystalline properties were studied by thermal gravimetric analysis (TGA), differential scanning calorimetric (DSC) and wide-angle X-ray diffraction (WXRD). The tensile assays were conducted to evaluate the mechanical properties. The results suggest that properties of such kind of poly(ether ester)s can be finely tuned by the relative content of two components. Synergistic interaction of two structurally distinctive parts endows the materials with high performance.
\end{abstract}

\section{Introduction}

With the development of human society, large number of industrial wastes is produced, and serious environmental pollution arises. In contrast, this outcome is disadvantageous to human health and the sustainable advance of economy. Consequently, human mankind needs to search the feasible solutions to these problems. ${ }^{1-6}$ At present, most of polymer materials are made from fossil resources, which are facing the severe problem of exhaustion. Scientists are hence looking for the renewable surrogates of petroleum-based starting materials. ${ }^{7-11}$

Nipagin and eugenol are two naturally occurring building blocks, which exist in campanulaceae plant and clove, respectively. ${ }^{12,13}$ These two starting materials have been found 
widespread applications in fields of liquid crystalline material, ${ }^{14,15}$ epoxy resin, ${ }^{16-18}$ benzoxazine, ${ }^{19,20}$ coating, ${ }^{21,22}$ and Li-S battery. ${ }^{23}$ Because of the multifunctionality (phenol and vinyl) and renewable nature of nipagin and eugenol, our group started to investigate polyester materials starting from them, whose thermal, crystalline, mechanical and degradable properties have been systematically investigated. ${ }^{24,25}$ The influence of monomer structure on final properties was also studied.$^{26}$ However, the comprehensive performance of prepared polyesters was still improvable, regardless of the renewability of starting materials. Either the glass transition temperatures $\left(T_{\mathrm{g}} \mathrm{s}\right)$ were not high enough, or the mechanical tough was not ideal. Consequently, further optimizing the performance of nipagin and eugenol-based polymer materials is particularly important for the development and utilization of such materials.

Considering the structural difference of nipagin and eugenol, the symmetrical nipagin units endow the polymers with high crystallinity and good mechanical strength, but poor flexibility and ductility. ${ }^{27,28}$ In contrast, eugenol-derived monomer is highly asymmetrical, which endows the polymers low crystallinity and poor mechanical strength, while their flexibility and ductility are good. ${ }^{24}$ Taking advantages of the complementary features of these two building blocks through rational molecular design may give the polymeric materials synergistic effect and excellent final properties. In this work, three nipagin and eugenol-derived diester monomers were firstly synthesized (Supplementary information, Fig. S1-S8), then melt polycondensation between diester monomers and 1,6-hexandiol were carried out. 1,6Hexandiol was chosen due to its renewability and high boiling point compared with short-chain ethylene glycol and 1,4-butanediol. ${ }^{29-32}$ Meanwhile, because the chain length of 1,6-hexandiol is shorter than 1,10-decanediol, the $T_{\mathrm{g}} \mathrm{s}$ of obtained polyesters was enhanced obviously compared with our previously synthesized polyesters with 1,10 -decanediol as the spacer. ${ }^{25}$

\section{Results}

\section{Synthesis and Structures of the Copoly(ether ester)s}

$\mathrm{PHN} 1_{1-\mathrm{x}} \mathrm{E} 1_{\mathrm{x}}$ and $\mathrm{PHN} 1_{1-\mathrm{x}} \mathrm{E} 2_{\mathrm{x}}$ copoly(ether ester)s were synthesized by melt polycondensation according to the predetermined composition ratios of nipagin and eugenol-derived dimethyl esters. The polymerization routes are shown in Fig. 1 and the

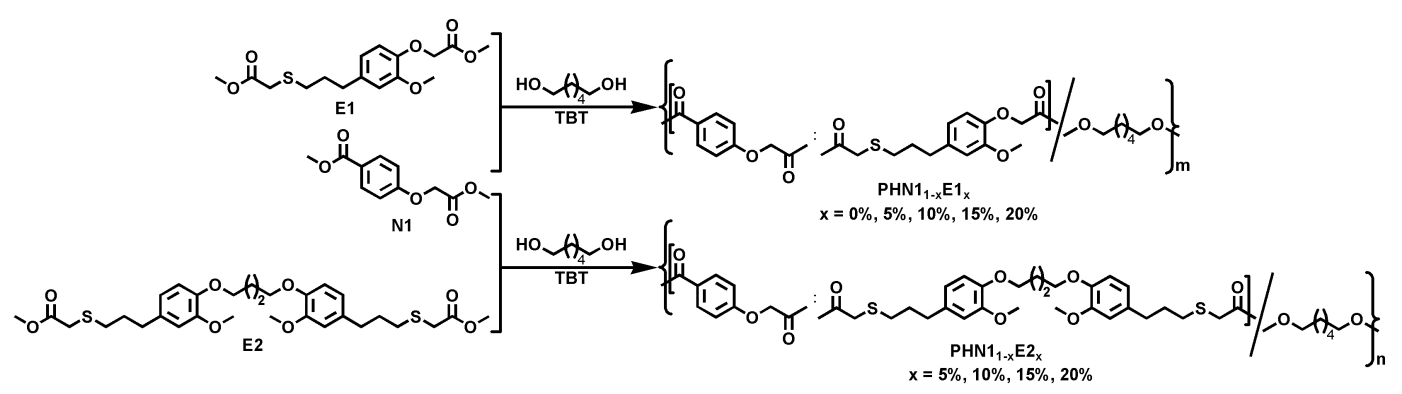

Figure 1. Synthetic routes for the preparation of nipagin and eugenol-based poly(ether ester)s. 
Table 1. Molar composition, molecular weight, polydispersity, isolated yield and status of the poly(ether ester)s

\begin{tabular}{|c|c|c|c|c|c|c|c|c|c|}
\hline \multirow[b]{3}{*}{ Poly(ether ester) } & \multirow[b]{3}{*}{ Yield $(\%)^{c}$} & \multicolumn{4}{|c|}{ Molar Composition } & & & & \multirow[b]{3}{*}{ Isolated state ${ }^{c}$} \\
\hline & & \multicolumn{2}{|c|}{ Feed ratio } & \multicolumn{2}{|c|}{ Final product $^{a}$} & \multicolumn{3}{|c|}{ Molecular Weight ${ }^{b}$} & \\
\hline & & $X_{\mathrm{N} 1}$ & $X_{\mathrm{E}}$ & $X_{\mathrm{N} 1}$ & $X_{\mathrm{E}}$ & $M_{\mathrm{n}}$ & $M_{\mathrm{w}}$ & $D$ & \\
\hline PHN1 & $92 \%$ & 100 & 0 & 100 & 0 & 14900 & 26300 & 1.8 & White powder \\
\hline PHN1 $_{95 \%} \mathbf{E 1}_{5 \%}$ & $87 \%$ & 95 & 5 & 94.3 & 5.7 & 13400 & 23600 & 1.8 & Light yellow powder \\
\hline PHN1 $_{90 \%} \mathbf{E 1}_{10 \%}$ & $88 \%$ & 90 & 10 & 90.4 & 9.6 & 10200 & 16900 & 1.7 & Light yellow powder \\
\hline PHN1 $_{85 \%} \mathbf{E 1}_{15 \%}$ & $86 \%$ & 85 & 15 & 84.7 & 15.3 & 10200 & 17200 & 1.7 & Light yellow powder \\
\hline PHN1 $_{80 \%} \mathbf{E 1}_{20 \%}$ & $85 \%$ & 80 & 20 & 80.3 & 19.7 & 13900 & 24000 & 1.7 & Light yellow semisolid \\
\hline PHN1 $_{95 \%} \mathbf{E 2}_{5 \%}$ & $87 \%$ & 95 & 5 & 94.3 & 5.7 & 15100 & 26800 & 1.8 & Light yellow powder \\
\hline PHN1 $_{90 \%} \mathbf{E 2} 2_{10 \%}$ & $85 \%$ & 90 & 10 & 89.3 & 10.7 & 13200 & 22400 & 1.7 & Light yellow powder \\
\hline PHN1 $_{85 \%}$ E2 $_{15 \%}$ & $86 \%$ & 85 & 15 & 84.0 & 16.0 & 13200 & 23000 & 1.7 & Light yellow semisolid \\
\hline PHN1 $_{80 \%}$ E2 $_{20 \%}$ & $82 \%$ & 80 & 20 & 78.7 & 21.3 & 11400 & 19900 & 1.7 & Light yellow semisolid \\
\hline
\end{tabular}

${ }^{a}$ Molar composition in final product determined by integration of the ${ }^{1} \mathrm{H}$ NMR spectrum. ${ }^{b}$ SEC carried out in THFGPC relative to PS calibrations. ${ }^{c}$ After purification by precipitating from excess amount of methanol.

results are summarized in Table 1. The SEC traces are depicted in Fig. S9-S10. The high yields suggest the high reactivity of these two kinds of monomers. The consistency of nipagin and eugenol-derived units in the feed and final product demonstrates that nipagin and eugenol-based diester monomers have similar reactivity and excellent compatibility. The polydispersity (D) values of the copoly(ether ester)s are found to be fixed at about 1.7 regardless of the feed ratios, which also suggest the similar reactivity of diester monomers. The apparent status of final products is closely related with the feed ratios. That is, with the gradual increase of eugenolbased units, the physical form of final product changes from white powder for PHN1, transforms into yellow powder for PHN1 $1_{95 \%} \mathrm{E} 1(2)_{5 \%}, \mathrm{PHN} 1_{90 \%} \mathrm{E} 1(2)_{10 \%}$, and $\mathrm{PHN} 1_{85} \mathrm{E} 1_{15 \%}$, finally becomes light yellow semisolid for PHN1 ${ }_{80} \mathrm{E} 1_{20 \%}$, $\mathrm{PHN} 1_{85} \mathrm{E} 2_{15 \%}$ and $\mathrm{PHN} 1_{80 \%} \mathrm{E} 2_{20 \%}$. This phenomenon indicates that eugenol-derived units are easier to be oxidized than nipaginderived units.

Chemical structures of the copoly(ether ester)s were confirmed by ${ }^{1} \mathrm{H}$ NMR (Fig. S11S12), ${ }^{13}$ C NMR (Fig. S13-S14) and FTIR spectroscopy (Fig. S15-S16). Furthermore, their chemical microstructures were studied using the quantitative ${ }^{13} \mathrm{C}$ NMR spectra taking advantage of the sensitiveness of magnetically different carbon atoms present in backbones towards sequence distributions at the dyed level. ${ }^{[33]}$ In the present study, the methylene carbons adjacent to the alcohol-oxygens were well resolved in the ${ }^{13} \mathrm{C}$ NMR spectra due to the asymmetrical feature of $\mathrm{N} 1$ and E1. They exhibited the difference of head and tail when incorporated into the polymer chains during copolymerizing. However, when N1 was copolymerized with E2, N1 displayed the difference of head and tail while the two ester groups in E2 were equivalent. The possible sequence distributions and splitting situation of methylene carbons in ${ }^{13} \mathrm{C}$ NMR spectra were depicted in Fig. 2 and Fig. S17, from which it can be observed that the signal intensities depend closely on the feed ratios of copoly(ether ester)s. Due to short chain of 1,6-hexanediol, the splitting of methylene carbons adjacent to the alcohol-oxygens were very sensitive to sequence distributions as shown in the case of PHN1 ${ }_{80 \%} \mathrm{E} 1_{20 \%}$. Chemical 
microstructure analysis demonstrated that $\mathrm{N} 1$ and E1(E2) were incorporated into the copoly(ether ester) chains in an arbitrary manner. Hence, the nipagin and eugenol-derived copoly(ether ester)s have completely random microstructures in polymer mainchains.
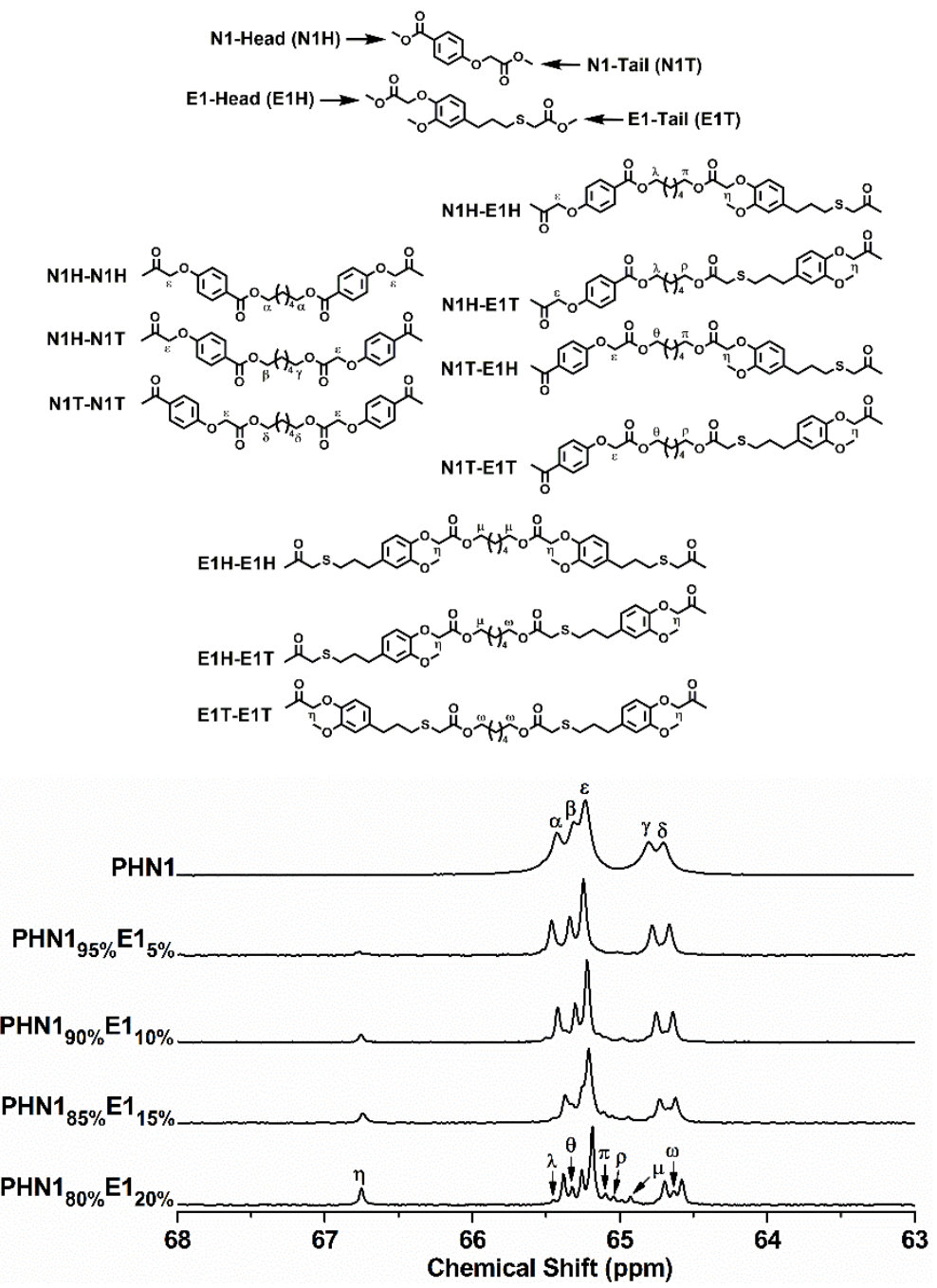

Figure 2. The splitting situations of methylene carbons adjacent to the alcohol-oxygen atoms for $P H N 1_{1-x} E 1_{x}$ with the indications of dyads to which they are assigned.

\section{Thermal Properties}

Thermal stabilities of the copoly(ether ester)s were investigated by thermogravimetric analysis (TGA). Weight-loss curves and the corresponding derivative curves are depicted in Fig. 3 and Fig. S18-S20, respectively. Thermal property parameters are summarized in Table 2 and the results suggest that $\mathrm{PHN} 1_{1-\mathrm{x}} \mathrm{E} 1_{\mathrm{x}}$ and $\mathrm{PHN} 1_{1-\mathrm{x}} \mathrm{E} 2_{\mathrm{x}}$ exhibit comparable thermal stability with the parent PHN1. Despite the content of eugenol-derived composition reached 20\%, the temperature at which $5 \%$ weight loss $\left(T_{5 \%}\right)$ decreased just about $10{ }^{\circ} \mathrm{C}$ for both $\mathrm{PHN} 1_{1-\mathrm{x}} \mathrm{E} 1_{\mathrm{x}}$ and PHN1 $1_{1-x} \mathrm{E} 2_{x}$ relative to PHN1. Furthermore, $\mathrm{PHN} 1_{1-\mathrm{x}} \mathrm{E} 1_{\mathrm{x}}$ and $\mathrm{PHN} 1_{1-\mathrm{x}} \mathrm{E} 2_{\mathrm{x}}$ exhibited almost the same thermal stability regardless that the ratio of eugenol-derived composition was identical or not. Based on the above results we can conclude that the incorporation of eugenol- derived units 


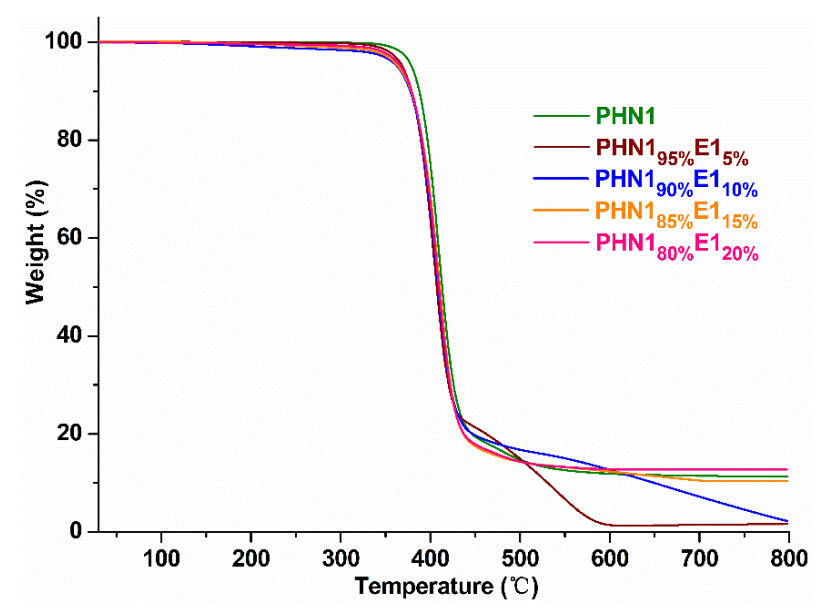

Figure 3. TGA curves of $\mathrm{PHN} 1_{1-\mathrm{x}} \mathrm{E} 1_{\mathrm{x}}$ recorded from $25-800{ }^{\circ} \mathrm{C}$ at a heating rate of $10{ }^{\circ} \mathrm{C} / \mathrm{min}$ under a nitrogen atmosphere.

Table 2. Thermal property parameters of the poly(ether ester)s.

\begin{tabular}{|c|c|c|c|c|}
\hline \multirow[b]{2}{*}{ Poly(ether ester)s } & \multicolumn{3}{|c|}{ TGA } & \multirow{2}{*}{ 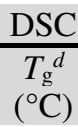 } \\
\hline & $\begin{array}{l}T_{5 \%}{ }^{a} \\
\left({ }^{\circ} \mathrm{C}\right)\end{array}$ & $\begin{array}{c}T_{\mathrm{d}}^{b} \\
\left({ }^{\circ} \mathrm{C}\right)\end{array}$ & $\begin{array}{l}W^{c} \\
(\%)\end{array}$ & \\
\hline PHN1 & 379 & $409 / 480$ & 11.3 & 13.1 \\
\hline PHN1 $_{95 \%} \mathbf{E 1}_{5 \%}$ & 368 & $405 / 537$ & 1.3 & 13.1 \\
\hline PHN1 $_{90 \%} \mathbf{E 1}_{10 \%}$ & 363 & $407 / 612$ & 2.2 & 7.7 \\
\hline PHN1 $_{85 \%} \mathbf{E 1}_{15 \%}$ & 363 & 410 & 10.2 & 7.7 \\
\hline PHN1 $_{80 \%} \mathbf{E 1}_{20 \%}$ & 367 & 408 & 12.8 & 4.8 \\
\hline PHN1 $_{95} \% \mathbf{E 2}_{5 \%}$ & 367 & 409 & 9.3 & 10.3 \\
\hline PHN1 $_{90 \%} \mathbf{E 2} 2_{10 \%}$ & 371 & 408 & 11.4 & 7.5 \\
\hline PHN1 $_{85 \%} \mathbf{E 2} \mathbf{1 5}_{15}$ & 371 & 409 & 8.8 & 5.0 \\
\hline PHN1 $_{80 \%} \mathbf{E 2} 2_{20 \%}$ & 366 & 410 & 10.4 & 4.6 \\
\hline
\end{tabular}

${ }^{a}$ Temperature at which $5 \%$ weight loss. ${ }^{b}$ Temperature for maximum degradation rate. ${ }^{c}$ Remaining weight at $800{ }^{\circ} \mathrm{C} .{ }^{d}$ Glass transition temperatures $\left(T_{\mathrm{g}}\right)$ taken as the inflection points of the second heating DSC traces of precipitated samples at a heating/cooling rate of $10^{\circ} \mathrm{C} / \mathrm{min}$.

did not influence thermal stability of the final product. $T_{5 \%}$ values are above $363{ }^{\circ} \mathrm{C}$ for all the samples. The temperature for maximum degradation rate $\left(T_{\mathrm{d}}\right)$ values were almost identical for both PHN1 and PHN1 $1_{1-\mathrm{x}} \mathrm{E} 1(2)_{\mathrm{x}}$, whose $T_{\mathrm{d}}$ values were hold at about $410{ }^{\circ} \mathrm{C}$ and found to be insusceptible to the changes of content in eugenol-derived composition. Furthermore, PHN1 $1_{1}$ ${ }_{\mathrm{x}} \mathrm{E} 1_{\mathrm{x}}$ with eugenol-derived composition below or equal to $10 \%$ features a two-step degradation mechanism. However, for $\mathrm{PHN}_{1-\mathrm{x}} \mathrm{E} 1_{\mathrm{x}}$ with eugenol-derived composition above $10 \%$ and the whole series of $\mathrm{PHN} 1_{1-\mathrm{x}} \mathrm{E} 2_{\mathrm{x}}$, single-step degradation is observed. This phenomenon can be explained by the mismatch of conformation of polymer chains at these specific compositions. Conclusion can be drawn from TGA analysis was that the copoly(ether ester)s feature excellent thermal stabilities, and the incorporation of eugenol-derived component actually has good compatibility with the parent PHN1.

Other thermal properties like glass transition $\left(T_{\mathrm{g}}\right)$, melting and crystallization temperatures $\left(T_{\mathrm{g}}, T_{\mathrm{m}}, T_{\mathrm{c}}\right)$, together with their corresponding melting and crystallization enthalpies $\left(\Delta H_{\mathrm{m}}, \Delta H_{\mathrm{c}}\right)$ 
are critical factors for both injection moulding and engineering applications. Here these properties were studied by differential scanning calorimetric analysis (DSC). The DSC heating traces $\left(2^{\text {nd }}\right)$ are shown in Fig. 4, and the analytical data are gathered in Table 2.

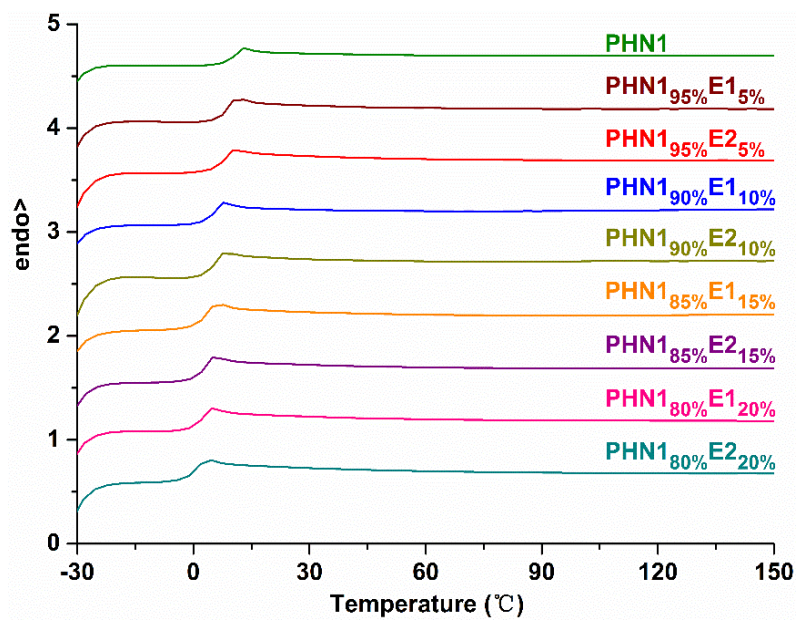

Figure 4. The second heating DSC curves for the poly(ether ester) samples carried out from 30 to $150{ }^{\circ} \mathrm{C}$ at a heating/cooling rate of $10^{\circ} \mathrm{C} / \mathrm{min}$.

Both $\mathrm{PHN} 1_{1-\mathrm{x}} \mathrm{E} 1_{\mathrm{x}}$ and $\mathrm{PHN} 1_{1-\mathrm{x}} \mathrm{E} 2_{\mathrm{x}}$ are found to exhibit solely obvious glass transition with $T_{\mathrm{g}}$ values ranging from 4.6 to $13.1{ }^{\circ} \mathrm{C}$, which have a progressing trend to decrease with the gradual increase of eugenol-based composition in each series. The gradual increase of asymmetrical eugenol- derived units and thus caused many free volumes for segmental motion and low $T_{\mathrm{g}}$. $\mathrm{PHN} 1_{1-\mathrm{x}} \mathrm{E} 1_{\mathrm{x}}$ has a slightly higher $T_{\mathrm{g}}$ value than $\mathrm{PHN} 1_{1-\mathrm{x}} \mathrm{E} 2_{\mathrm{x}}$, suggesting that $\mathrm{PHN} 1_{1-}$ ${ }_{x} E 2_{x}$ features a better flexibility than $P H N 1_{1-x} E 1_{x}$ when the content of eugenol-derived composition is the same.The single glass transition in the second heating runs for both two series of copoly(ether ester)s suggests that these samples could not crystallize from the melt during the first cooling run at the given cooling rate of $10{ }^{\circ} \mathrm{C} / \mathrm{min}$. The locally ordered packing of chain segments was not favoured at such conditions. Although the $T_{\mathrm{g}}$ values gradually decreased with the incorporation of eugenol-derived units, the values changed not so much and were still in the scope of practical applications.

\section{Powder X-ray Diffraction Analysis}

Powder wide-angle X-ray diffraction analysis (WXRD) was performed to further verify the DSC results. The WXRD traces are depicted in Fig. 5 and Fig. S21, and the diffraction data are collected in Table 3. All the samples were not able to form well discrete diffraction peaks characteristic of amorphous materials. The scattering pattern for PHN1 is characterized by three reflections at $19.04^{\circ}, 21.92^{\circ}$, and $25.66^{\circ}$, respectively, which corresponds to the triclinic crystal structure just like displayed by PBT. ${ }^{[34,35]}$ Almost the same diffraction pattern was observed for all the poly(ether ester) materials if the diffraction angles and relative intensities were considered, indicating the 


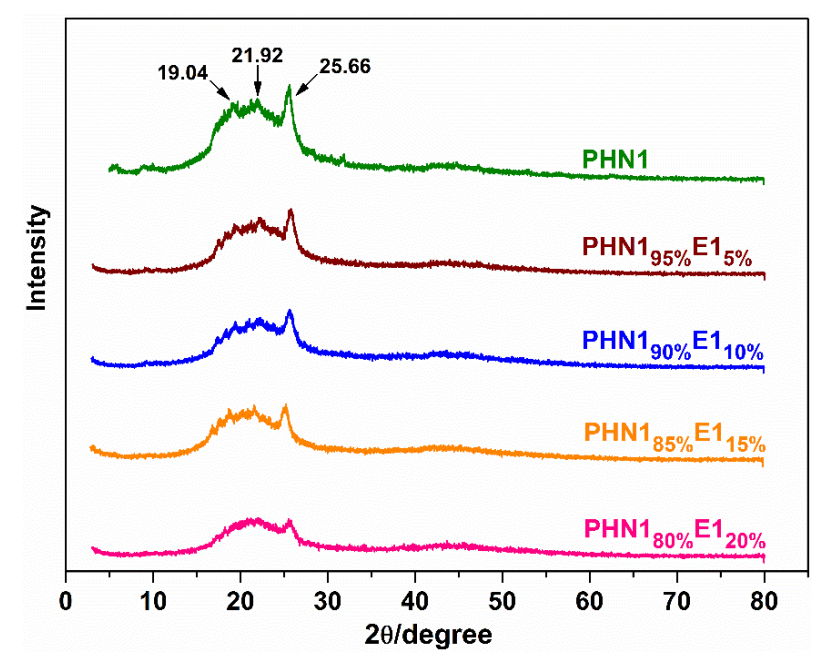

Figure 5. Powder WXRD profiles for PHN1 and PHN1 1-x $E 1_{x}$.

Table 3. Powder X-ray diffraction data for the poly(ether ester)s.

\begin{tabular}{|c|c|c|c|c|}
\hline \multirow{2}{*}{$\begin{array}{l}\text { Poly(ether } \\
\text { ester) }\end{array}$} & \multicolumn{4}{|c|}{ X-ray diffraction data } \\
\hline & & $\theta\left({ }^{\circ}\right)^{a}$ & & $X_{c}^{b}$ \\
\hline PHN1 & $19.04 \mathrm{~m}$ & $21.92 \mathrm{~m}$ & $25.66 \mathrm{~s}$ & 0.22 \\
\hline PHN195\%E15\% & $19.04 \mathrm{~m}$ & $21.92 \mathrm{~m}$ & $25.66 \mathrm{~s}$ & 0.19 \\
\hline PHN190\%E1 10\% & $19.04 \mathrm{~m}$ & $21.92 \mathrm{~m}$ & $25.66 \mathrm{~s}$ & 0.18 \\
\hline PHN1 $_{85 \% E 1}{ }_{15 \%}$ & $19.04 \mathrm{~m}$ & $21.92 \mathrm{~m}$ & $25.66 \mathrm{~s}$ & 0.16 \\
\hline PHN1 $80 \% \mathbf{E 1} 20 \%$ & $19.04 \mathrm{w}$ & $21.92 \mathrm{~W}$ & $25.66 \mathrm{~m}$ & 0.15 \\
\hline PHN195\%E25\% & $19.04 \mathrm{~m}$ & $21.92 \mathrm{~m}$ & $25.66 \mathrm{~s}$ & 0.18 \\
\hline PHN190\%E2 $_{10 \%}$ & $19.04 \mathrm{~m}$ & $21.92 \mathrm{~m}$ & $25.66 \mathrm{~s}$ & 0.16 \\
\hline PHN185\%E215\% & $19.04 \mathrm{w}$ & $21.92 \mathrm{w}$ & $25.66 \mathrm{~m}$ & 0.15 \\
\hline PHN180\%E2 $20 \%$ & $19.04 \mathrm{w}$ & $21.92 \mathrm{w}$ & $25.66 \mathrm{~m}$ & 0.13 \\
\hline
\end{tabular}

${ }^{a}$ The diffraction angles measured in powder diffraction patterns for samples coming directly from precipitation in methanol and dried overnight. Intensities visually estimated as follows: m: medium; s: strong; w: weak. ${ }^{b}$ Crystallinity index calculated as the quotient between crystalline area and total area. Crystalline and amorphous areas in the X-ray diffraction pattern were quantified using PeakFit v4.12 software.

crystalline mode of PHN1 was maintained in the copoly(ether ester)s. The crystallinity values can be calculated as the quotient between crystalline area and total area of the diffraction traces. The copoly(ether ester)s were found to be semi-crystalline and the crystallinities decrease with the increase of eugenol-derived composition. The discrepancy of material attribute from DSC and WXRD analysis can be ascribed to the difference of treatment method. The samples for WXRD were directly from precipitation in methanol, resulting in a certain degree of crystallization. The X-ray diffraction results confirm that the materials still feature slightly crystalline properties, rather than completely amorphous materials. The crystallinities gradually decrease with the insertion of eugenol-derived units.

\section{Stress-Strain Behavior}

To study the synergistic effect of nipagin and eugenol-based components on mechanical properties, tensile assays of $\mathrm{PHN} 1_{1-\mathrm{x}} \mathrm{E} 1_{\mathrm{x}}$ and $\mathrm{PHN} 1_{1-\mathrm{x}} \mathrm{E} 2_{\mathrm{x}}$ copoly(ether ester)s were performed on dumb-bell shaped specimens $\left(12 \times 2 \times 0.5 \mathrm{~mm}^{3}\right)$, which were prepared by casting the 


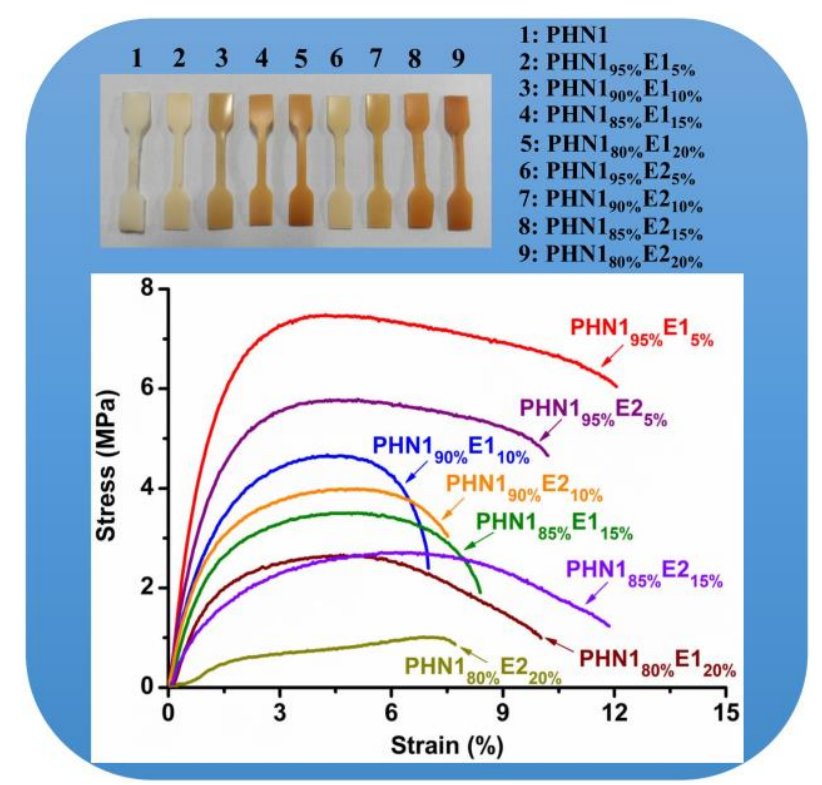

Figure 6. Stress-strain samples and curves of the poly(ether ester)s.

Table 4. Mechanical property parameters for the poly(ether ester)s.

\begin{tabular}{|c|c|c|c|}
\hline \multirow[b]{2}{*}{$\begin{array}{l}\text { Poly(ether } \\
\text { ester) }\end{array}$} & \multicolumn{3}{|c|}{ Mechanical Properties } \\
\hline & $\begin{array}{l}\text { Young's modulus } \\
\text { (MPa) }\end{array}$ & $\begin{array}{c}\text { Tensile strength } \\
(\mathrm{MPa})\end{array}$ & $\begin{array}{c}\text { Elongation at break } \\
(\%)\end{array}$ \\
\hline PHN1 & $696 \pm 24$ & $17.2 \pm 1.5$ & $14.5 \pm 2.2$ \\
\hline PHN195\%E1 $5 \%$ & $240.0 \pm 14$ & $7.5 \pm 1.2$ & $12.1 \pm 4.2$ \\
\hline PHN190\%E1 $10 \%$ & $146.7 \pm 12$ & $4.7 \pm 2.1$ & $7.0 \pm 3.6$ \\
\hline PHN1 $_{85 \%}$ E1 $1_{15 \%}$ & $110.0 \pm 16$ & $3.5 \pm 1.5$ & $8.4 \pm 5.0$ \\
\hline PHN1 ${ }_{80 \%}$ E1 $20 \%$ & $83.3 \pm 11$ & $2.7 \pm 1.8$ & $10.0 \pm 4.5$ \\
\hline PHN195\% E2 $5 \%$ & $183.3 \pm 28$ & $5.8 \pm 1.5$ & $10.2 \pm 2.4$ \\
\hline PHN190\% $\mathbf{E 2} 10 \%$ & $123.3 \pm 25$ & $4.0 \pm 1.7$ & $7.5 \pm 3.2$ \\
\hline PHN1 ${ }_{85} \% \mathbf{E 2}{ }_{15 \%}$ & $57.7 \pm 12$ & $2.7 \pm 0.8$ & $11.9 \pm 4.8$ \\
\hline PHN1 $_{80} \% \mathbf{E 2} 20 \%$ & $33.3 \pm 8$ & $1.0 \pm 0.6$ & $7.7 \pm 4.6$ \\
\hline
\end{tabular}

chloroform solution $\left(0.1 \mathrm{~g} \mathrm{~mL}^{-1}\right)$. The stress-stain curves were depicted in Fig. 6 and the mechanical property data were summarized in Table 4. Young's modulus and tensile strength were found to decrease with the increase of eugenol-derived units in each series of samples. Furthermore, Young's modulus and tensile strength for $\mathrm{PHN} 1_{1-\mathrm{x}} \mathrm{E} 1_{\mathrm{x}}$ was slightly higher than those of $P H N 1_{1-x} E 2_{x}$ when the content of eugenol-derived composition was the same. However, the elongations at break firstly decrease and then increase with the content of eugenol-derived composition increasing. For example, elongations at break decreased from $14.5 \%$ for PHN1 (the data of PHN1 here are original ${ }^{[36]}$ to $7.0 \%$ for $\mathrm{PHN} 1_{90 \%} \mathrm{E} 1_{10 \%}$, and then increased to $10.0 \%$ for $\mathrm{PHN} 1_{80 \%} \mathrm{E} 1_{20 \%}$. The conclusion that can be drawn from tensile assays is that the incorporation of eugenol-derived composition impedes the crystallization of copoly(ether ester)s significantly and thus caused the lower Young's modulus and tensile strength, together with the tunable elongation at break. The harmony synergistic effect of nipagin and eugenolderived composition could result in Young's modulus, tensile strength or elongation at break in a desired application scope. 


\section{Discussion}

In order to prepare further sustainable and practical polymer materials from naturally occurring biomass, renewable nipagin and eugenol-based aromatic copoly(ether ester) materials were synthesized via the melt polycondensation method. The effect of introduction of eugenol-derived units on thermal, crystalline, and mechanical properties was emphatically studied. TGA results revealed that the copoly(ether ester)s featured fairly high thermal stability despite the content of eugenol-derived composition reached 20\%. DSC and WXRD data suggested the amorphous nature for both homopoly(ether ester) and copoly(ether ester)s, regardless of the content of highly asymmetrical eugenol-based composition. Young's modulus and tensile strengths were also found a decreasing tendency with the insertion of eugenol-based composition. More importantly, elongation at break can be tunable via the different content of eugenol-based composition. The cooperative interaction of renewable nipagin and eugenolderived building blocks provides a practical and suitable way to obtain polymeric materials with excellent performance.

\section{Methods}

\section{Preparation of Nipagin and Eugenol-based Copoly(ether ester)s}

PHN1 homopoly(ether ester) and PHN1 $1_{1-x} E 1_{x}, P H N 1_{1-x} E 2_{x}(x=0 \%, 5 \%, 10 \%, 15 \%, 20 \%)$ copoly(ether ester)s were prepared from the mixtures of N1, E1 or E2, and 1,6-hexanediol with the predetermined composition content. The polymerization was performed in a $25 \mathrm{~mL}$ Schleck round-bottom flask equipped with a nitrogen inlet, a vacuum distillation outlet, and a magnetic stirrer bar. The polymerization scheme is illustrated in Fig. 1. A slight excess molar ratio of diesters to diol (1:1.05) was employed to ensure complete polymerization of ester groups. Tetrabutyl titanate (TBT, $0.6 \%$ molar relative to diester) was adopted as the catalyst. Before transesterification, the system was purged with nitrogen for 15 minutes to ensure no oxygen remaining and to avoid being oxidized during polymerization. Transesterification was carried out under a low nitrogen flow at $140-180{ }^{\circ} \mathrm{C}$ for 3-5 hours. Polycondensation was then carried out under a 0.03-0.06 mbar vacuum at $180-200{ }^{\circ} \mathrm{C}$ for 3-5 hours until stirrer bar was stuck, suggesting the completion of polymerization. The reaction mixture was cooled down to room temperature, while normal pressure was recovered with nitrogen to prevent degradation of product. The crude product was dissolved in a minimum amount of chloroform and precipitated in excess of methanol to remove oligomers and the excess diols. Final product was collected by filtration, thoroughly washed with methanol, and dried in vacuo.

PHN1 homopoly(ether ester). ${ }^{1} \mathrm{H}$ NMR (400 MHz, $25{ }^{\circ} \mathrm{C}, \mathrm{CDCl}_{3}$, TMS): $\delta=7.99-7.97$ (m, 2H, Ar- $H$ ), 6.91-6.89 (m, 2H, Ar- $H$ ), 4.66 (s, 2H, -O-CH $H_{2}-\mathrm{CO}-$ ), 4.27-4.17 (m, 4H, -COO$\left.\mathrm{CH}_{2}-\right), 1.76-1.62\left(\mathrm{~m}, 4 \mathrm{H},-\mathrm{COOCH}_{2}-\mathrm{CH}_{2}-\right), 1.49-1.25\left(\mathrm{~m}, 4 \mathrm{H},-\mathrm{COOCH}_{2} \mathrm{CH}_{2}-\mathrm{CH}_{2}-\right)$ ppm; ${ }^{13} \mathrm{C}$ 
NMR (100.6 MHz, $\left.25^{\circ} \mathrm{C}, \mathrm{CDCl}_{3}, \mathrm{TMS}\right): \delta=168.02\left(-\mathrm{OCH}_{2}-\mathrm{CO}-\right), 165.68$ (Ar-CO-), 161.13 (Ar-C), 131.23 (Ar-C), 123.47 (Ar-C), 113.91 (Ar-C), 64.98-64.78 (m, -O-CH 64.23 (m, -COO- $\mathrm{CH}_{2}-$ ), 28.34-28.00 (m, - $\mathrm{OCH}_{2}-\mathrm{CH}_{2}$ ), 25.45-24.98 (m, - $\mathrm{OCH}_{2} \mathrm{CH}_{2}-\mathrm{CH}_{2}$ ) ppm; FTIR: 2949, $1781(\mathrm{C}=\mathrm{O}), 1711(\mathrm{C}=\mathrm{O})$, 1606, 1510, 1253, 1170, 1105, 977, 848, 770, 697 $\mathrm{cm}^{-1}$.

PHN1 1-x E1 $x$ copoly(ether ester)s. ${ }^{1} \mathrm{H}$ NMR (400 MHz, $\left.25^{\circ} \mathrm{C}, \mathrm{CDCl}_{3}, \mathrm{TMS}\right): \delta=7.95-7.93$ $\{\mathrm{m},(1-\mathrm{x}) \cdot 2 \mathrm{H} ; \mathrm{Ar}-H\}, 6.88-6.86\{\mathrm{~m},(1-\mathrm{x}) \cdot 2 \mathrm{H} ; \mathrm{Ar}-H\}, 6.72-6.68(\mathrm{~m}, \mathrm{x} \cdot 2 \mathrm{H} ; \mathrm{Ar}-H), 6.63-6.61$ (m, $\mathrm{x} \cdot \mathrm{H} ; \mathrm{Ar}-H), 4.63\left\{\mathrm{~s},(1-\mathrm{x}) \cdot 2 \mathrm{H}\right.$; ArO-CH$\left.{ }_{2}-\mathrm{CO}-\right\}, 4.60$ (s, x-2H; ArO-CH2-CO-), 4.30-4.09 \{m, $\left.(1-\mathrm{x}) \cdot 4 \mathrm{H} ;-\mathrm{COO}-\mathrm{CH}_{2}-\right\}, 4.15-4.02\left(\mathrm{~m}, \mathrm{x} \cdot 4 \mathrm{H} ;-\mathrm{COO}-\mathrm{CH}_{2}-\right), 3.81\left(\mathrm{~s}, \mathrm{x} \cdot 3 \mathrm{H} ; \mathrm{ArO}-\mathrm{CH}_{3}\right), 3.16(\mathrm{~s}$, $\mathrm{x} \cdot 2 \mathrm{H}$; -S-CH $-\mathrm{CO}-$ ), 2.62-2.57 (m, x $\left.4 \mathrm{H} ; \mathrm{Ar}^{-} \mathrm{CH}_{2}-\mathrm{CH}_{2}-\mathrm{CH}_{2}-\mathrm{S}-\right), 1.88-1.81\left\{\mathrm{q},{ }^{3} \mathrm{~J}(\mathrm{H}, \mathrm{H})=8.0 \mathrm{~Hz}\right.$, $\left.\mathrm{x} \cdot 2 \mathrm{H} ; \mathrm{ArCH}_{2}-\mathrm{CH}_{2}-\mathrm{CH}_{2} \mathrm{~S}-\right\}, 1.79-1.65\left\{\mathrm{~m},(1-\mathrm{x}) \cdot 2 \mathrm{H} ; \mathrm{ArCOOCH}_{2}-\mathrm{CH}_{2}\right\}, 1.65-1.52\{\mathrm{~m},(1-$ $\left.\mathrm{x}) \cdot 2 \mathrm{H}+\mathrm{x} \cdot 4 \mathrm{H} ;-\mathrm{COOCH}_{2}-\mathrm{CH}_{2}-\right\}, 1.50-1.17\left\{\mathrm{~m},(1-\mathrm{x}) \cdot 4 \mathrm{H}+\mathrm{x} \cdot 4 \mathrm{H} ;-\mathrm{COOCH}_{2} \mathrm{CH}_{2}-\mathrm{CH}_{2}\right\} \mathrm{ppm} ;{ }^{13} \mathrm{C}$ NMR (100.6 MHz, $\left.25{ }^{\circ} \mathrm{C}, \mathrm{CDCl}_{3}, \mathrm{TMS}\right): \delta=170.48$ (- $\left.\mathrm{SCH}_{2}-\mathrm{CO}-\right), 169.18$ ( $\mathrm{ArOCH}_{2}-\mathrm{CO}-$ ), $168.29\left(\mathrm{ArOCH}_{2}-\mathrm{CO}-\right), 166.02$ (Ar-CO-), 161.38 (Ar-C), $149.54(\mathrm{Ar}-\mathrm{C}), 145.59$ (Ar-C), 135.74 (Ar-C), 131.51 (Ar-C), $123.82(\mathrm{Ar}-C), 120.23$ (Ar-C), 114.63 (Ar-C), $114.17(\mathrm{Ar}-C)$, 112.60 (Ar- $\mathrm{C}$ ), 66.68 and 65.11 (ArO- $\left.\mathrm{CH}_{2}-\mathrm{CO}-\right)$, 65.38-64.50 (-COO- $\mathrm{CH}_{2}-$ ), 55.87 ( $\left.\mathrm{ArO}-\mathrm{CH}_{3}\right)$, 34.15 (-S-CH $2-\mathrm{CO}-), 33.59$ ( $\left.\mathrm{Ar}-\mathrm{CH}_{2}-\mathrm{CH}_{2} \mathrm{CH}_{2} \mathrm{~S}-\right), 31.99$ (-S- $\left.\mathrm{CH}_{2}-\mathrm{CH}_{2} \mathrm{CH}_{2} \mathrm{Ar}\right), 30.50\left(\mathrm{ArCH}_{2}-\right.$ $\mathrm{CH}_{2}-\mathrm{SCH}_{2}$ ), 28.67-28.54 (m, - $\mathrm{COOCH}_{2}-\mathrm{CH}_{2}-$ ), 28.40-28.27 (m, - $\mathrm{COOCH}_{2} \mathrm{CH}_{2}-\mathrm{CH}_{2}$ ) ppm; FTIR: 2934, 2860, $1756(\mathrm{C}=\mathrm{O}), 1703(\mathrm{C}=\mathrm{O}), 1603,1510,1422,1265,1166,1105,1070,974$, $846,765,693 \mathrm{~cm}^{-1}$.

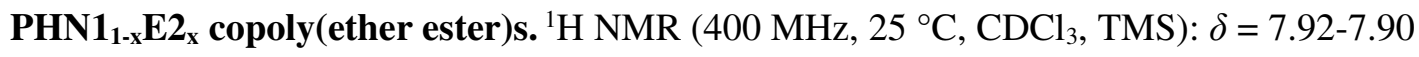
$\{\mathrm{m},(1-\mathrm{x}) \cdot 2 \mathrm{H} ; \mathrm{Ar}-H\}, 6.85-6.83\{\mathrm{~m},(1-\mathrm{x}) \cdot 2 \mathrm{H} ; \mathrm{Ar}-H\}, 6.73-6.71(\mathrm{~m}, \mathrm{x} \cdot \mathrm{H} ; \mathrm{Ar}-H), 6.63-6.59(\mathrm{~m}$, $\mathrm{x} \cdot 2 \mathrm{H} ; \mathrm{Ar}-\mathrm{H}), 4.59\left\{\mathrm{~s},(1-\mathrm{x}) \cdot 2 \mathrm{H}\right.$; ArO-CH $\left.2_{2} \mathrm{CO}-\right\}, 4.19-4.10\left\{\mathrm{~m},(1-\mathrm{x}) \cdot 4 \mathrm{H} ;-\mathrm{COO}_{-} \mathrm{CH}_{2}-\right\}, 4.03-$ $3.97\left\{\mathrm{~m},(1-\mathrm{x}) \cdot 4 \mathrm{H}+\mathrm{x} \cdot 4 \mathrm{H}\right.$; $\mathrm{ArO}-\mathrm{CH}_{2}-\mathrm{CH}_{2}-$ and $\left.-\mathrm{COO}-\mathrm{CH}_{2}-\right\}, 3.75\left(\mathrm{~s}, \mathrm{x} \cdot 6 \mathrm{H} ; \mathrm{ArO}-\mathrm{CH}_{3}\right), 3.13$ (s, $\mathrm{x} \cdot 4 \mathrm{H}$; $-\mathrm{S}-\mathrm{CH}_{2}-\mathrm{CO}-$ ), 2.67-2.46 (m, x-8H; Ar- $\mathrm{CH}_{2}-\mathrm{CH}_{2}-\mathrm{CH}_{2}-\mathrm{S}-$ ), 2.02-1.88 (m, x $4 \mathrm{H} ; \mathrm{ArOCH}_{2}-$ $\left.\mathrm{CH}_{2}-\right), 1.88-1.76\left\{\mathrm{q},{ }^{3} \mathrm{~J}(\mathrm{H}, \mathrm{H})=8.0 \mathrm{~Hz}, \mathrm{x} \cdot 4 \mathrm{H} ; \mathrm{ArCH}_{2}-\mathrm{CH}_{2}-\mathrm{CH}_{2} \mathrm{~S}-\right\}, 1.75-1.63\{\mathrm{~m},(1-\mathrm{x}) \cdot 2 \mathrm{H}$; $\left.\mathrm{ArCOOCH}_{2}-\mathrm{CH}_{2}-\right\}, 1.62-1.47\left\{\mathrm{~m},(1-\mathrm{x}) \cdot 2 \mathrm{H}+\mathrm{x} \cdot 4 \mathrm{H} ;-\mathrm{COOCH}_{2}-\mathrm{CH}_{2}-\right), 1.46-1.12\{\mathrm{~m},(1-\mathrm{x}) \cdot 4 \mathrm{H}+$ $\mathrm{x} \cdot 4 \mathrm{H}$; $\left.-\mathrm{COOCH}_{2} \mathrm{CH}_{2}-\mathrm{CH}_{2}-\right\}$ ppm; ${ }^{13} \mathrm{C} \mathrm{NMR}\left(100.6 \mathrm{MHz}, 25{ }^{\circ} \mathrm{C}, \mathrm{CDCl}_{3}, \mathrm{TMS}\right): \delta=170.29(-$ $\mathrm{SCH}_{2}-\mathrm{CO}$ ), 168.09 ( $\left.\mathrm{ArOCH}_{2}-\mathrm{CO}-\right), 165.78$ (Ar-CO-), 161.22 (Ar-C), 149.20 (Ar-C), 146.57 (Ar-C), 133.87 (Ar-C), 131.31 (Ar-C), $123.62(\mathrm{Ar}-C), 120.13$ (Ar-C), 114.00 (Ar-C), 113.21 $(\mathrm{Ar}-\mathrm{C}), 112.20$ (Ar- $\mathrm{C}), 68.58$ (ArO- $\mathrm{CH}_{2}-\mathrm{CH}_{2}$ ), 64.90 (ArO- $\left.\mathrm{CH}_{2}-\mathrm{CO}-\right)$, 64.42-64.31 (-COO$\left.\mathrm{CH}_{2}-\right)$, 55.71 ( $\left.\mathrm{ArO}-\mathrm{CH}_{3}\right), 33.95$ (-S-CH $\left.\mathrm{CH}_{2} \mathrm{CO}-\right), 33.39$ ( $\left.\mathrm{Ar}-\mathrm{CH}_{2}-\mathrm{CH}_{2} \mathrm{CH}_{2} \mathrm{~S}-\right), 31.81\left(-\mathrm{S}-\mathrm{CH}_{2}-\right.$ $\left.\mathrm{CH}_{2} \mathrm{CH}_{2} \mathrm{Ar}\right), 30.42\left(\mathrm{ArCH}_{2}-\mathrm{CH}_{2}-\mathrm{SCH}_{2}-\right), 28.43-28.15$ (m, - $\left.\mathrm{COOCH}_{2}-\mathrm{CH}_{2}-\right), 25.84\left(\mathrm{ArOCH}_{2}-\right.$ $\mathrm{CH}_{2}$ ), 25.53-25.06 (m, - $\left.\mathrm{COOCH}_{2} \mathrm{CH}_{2}-\mathrm{CH}_{2}{ }^{-}\right)$ppm; FTIR: 2935, 2860, $1756(\mathrm{C}=\mathrm{O}), 1708$ $(\mathrm{C}=\mathrm{O}), 1603,1510,1459,1264,1166,1107,1071,976,847,809,765,693 \mathrm{~cm}^{-1}$. 


\section{References}

1. Schutyser, W. et al. Chemicals from lignin: an interplay of lignocellulose fractionation, depolymerisation, and upgrading. Chem. Soc. Rev. 47, 852-908 (2018).

2. Sheldon, R. \& Woodley, J. Role of biocatalysis in sustainable chemistry. Chem. Rev. 118, 801-838 (2018).

3. Mika, L., Cséfalvay, E. \& Németh, Á. Catalytic conversion of carbohydrates to initial platform chemicals: chemistry and sustainability. Chem. Rev. 118, 505-613 (2018).

4. Zhang, L., Liu, Z., Cui, G. \& Chen, L. Biomass-derived materials for electrochemical energy storages. Prog. Polym. Sci. 43, 136-164 (2015).

5. Douka, A., Vouyiouka, S., Papaspyridi, L. \& Papaspyrides, C. A review on enzymatic polymerization to produce polycondensation polymers: The case of aliphatic polyesters, polyamides and polyesteramides. Prog. Polym. Sci. 79, 1-25 (2018).

6. Varma, R. Biomass-derived renewable carbonaceous materials for sustainable chemical and environmental applications. ACS Sustain. Chem. Eng. 7, 6458-6470 (2018).

7. Gallezot, P. Conversion of biomass to selected chemical products. Chem. Soc. Rev. 41, 1538-1558 (2012).

8. Lambert, S. \& Wagner, M. Environmental performance of bio-based and biodegradable plastics: the road ahead. Chem. Soc. Rev. 46, 6855-6871 (2017).

9. Zhu, Y., Romain, C. \& Williams, C. Sustainable polymers from renewable resources. Nature. 540, 354-362 (2016).

10. John, G., Nagarajan, S., Vemula, P., Silverman, J. \& Pillai, C. Natural monomers: a mine for functional and sustainable materials - occurrence, chemical modification and polymerization. Prog. Polym. Sci. 92, 158-209 (2019).

11. Wang, Z., Ganewatta, M. \& Tang, C. Sustainable polymers from biomass: bridging chemistry with materials and processing. Prog. Polym. Sci. 101, 101197 (2020).

12. Lummiss, J. et al. Chemical plants: high-value molecules from essential oils. J. Am. Chem. Soc. 134, 18889-18891 (2012).

13. Tomizawa, S., Chuah, J., Matsumoto, K., Doi, Y. \& Numata, K. Understanding the limitations in the biosynthesis of polyhydroxyalkanoate (PHA) from lignin derivatives. ACS Sustain. Chem. Eng. 2, 1106-1113 (2014).

14. Chen, X. et al. Design, synthesis, and characterization of bent-core mesogen-jacketed liquid crystalline polymers. Macromolecules. 39, 517-527 (2006). 
15. Chien, C. \& Liu, J. Optical behaviors of cholesteric liquid-crystalline polyester composites with various chiral photochromic dopants. Langmuir. 31, 13410-13419 (2015).

16. Faye, I., Decostanzi, M., Ecochard, Y. \& Caillol, S. Eugenol bio-based epoxy thermosets: from cloves to applied materials. Green. Chem. 19, 5236-5242 (2015).

17. Chen, C., Tung, S., Jeng, R., Abu-Omar, M. \& Lin, C. A facile strategy to achieve fully bio-based epoxy thermosets from eugenol. Green. Chem. 21, 4475-4488 (2019).

18. Chen, C., Lin, C., Juang, T., Abu-Omar, M. \& Lin, C. The reaction of activated esters with epoxides for self-curable, highly flexible, $\mathrm{A}_{2} \mathrm{~B}_{2}$ - and $\mathrm{A}_{3} \mathrm{~B}_{3}$-type epoxy compounds. Polym. Chem. 10, 3983-3995 (2019).

19. Teng, N. et al. Making benzoxazine greener and stronger: renewable resource, microwave irradiation, green solvent, and excellent thermal properties. ACS Sustain. Chem. Eng. 7, 8715-8723 (2019).

20. Shi, W. et al. Sustainable preparation of bio-based polybenzoxazine resins from amino acid and their application in $\mathrm{CO}_{2}$ adsorption. ACS Sustain. Chem. Eng. 7, 1731317324 (2019).

21. Watanabe, H., Takahashi, M., Kihara, H. \& Yoshida, M. Photocurable urushiol analogues bearing methacryloxy-containing side chains. Langmuir. 35, 4534-4539 (2019).

22. Breloy, L. et al. $\beta$-Carotene/limonene derivatives/eugenol: green synthesis of antibacterial coatings under visible-light exposure. ACS Sustain. Chem. Eng. 7, 1959119604 (2019).

23. Hoefling, A., Nguyen, D., Lee, Y., Song, S. \& Theato, P. A sulfur-eugenol allyl ether copolymer: a material synthesized via inverse vulcanization from renewable resources and its application in Li-S batteries. Mater. Chem. Front. 1, 1818-1822 (2017).

24. Hu, K., Zhao, D., Wu, G. \& Ma, J. Synthesis and properties of polyesters derived from renewable eugenol and $\alpha, \omega$-diols via a continuous overheating method. Polym. Chem. 6, 7138-7148 (2015).

25. Hu, K., Zhao, D., Wu, G. \& Ma, J. Toughened aromatic poly-(decylene terephthalate) copolyesters with two renewable eugenol-based components via a random copolymerization method. Polym. Chem. 7, 1096-1110 (2016).

26. Hu, K., Zhao, D., Wu, G. \& Ma, J. Bio-based aromatic copoly(ether ester)s with enhanced toughness and degradability: influence of insertion of phenoxy-ether linkage 
and eugenol-derived composition on properties. J Polym. Sci. Part A: Polym. Chem. 54, 2171-2183 (2016).

27. Martella, D., Parmeggiani, C., Wiersma, D., Piñol, M. \& Oriol, L. The first thiol-yne click chemistry approach for the preparation of liquid crystalline elastomers. J Mater. Chem. C. 3, 9003-9010 (2015).

28. Wilsens, C. et al. Improving stiffness, strength, and toughness of poly $(\omega-$ pentadecalactone) fibers through in situ reinforcement with a vanillic acid-based thermotropic liquid crystalline polyester. Macromolecules. 49, 2228-2237 (2016).

29. Japu, C. et al. Bio-based aromatic copolyesters made from 1,6-hexanediol and bicyclic diacetalized D-glucitol. Polym. Chem. 3, 2092-2101 (2012).

30. Burt, S. et al. Production of 1,6-hexanediol from tetrahydropyran-2-methanol by dehydration-hydration and hydrogenation. Green. Chem. 19, 1390-1398 (2017).

31. Warlin, N. et al. A rigid spirocyclic diol from fructose-based 5hydroxymethylfurfural: synthesis, life-cycle assessment, and polymerization for renewable polyesters and poly(urethane-urea)s. Green. Chem. 21, 6667-6684 (2019).

32. He, J. et al. Synthesis of 1,6-hexanediol from cellulose derived tetrahydrofurandimethanol with $\mathrm{Pt}-\mathrm{WO}_{\mathrm{x}} / \mathrm{TiO}_{2}$ Catalysts. ACS Catal. 8, 1427-1439 (2018).

33. Japu, C. et al. D-glucose-derived PET copolyesters with enhanced $T_{\mathrm{g}}$. Polym. Chem. 4, 3524-3536 (2013).

34. Japu, C. et al. Bio-based PBT copolyesters derived from D-glucose: influence of composition on properties. Polym. Chem. 5, 3190-3202 (2014).

35. Shen, Z. et al. A study on mediating the crystallization behavior of PBT through intermolecular hydrogen-bonding. RSC Adv. 6, 17510-17518 (2016).

36. Hu, K., Zhao, D., Wu, G. \& Ma, J. Aromatic poly(ether ester)s derived from a naturally occurring building block nipagin and linear aliphatic $\alpha, \omega$-diols. RSC Adv. 7, 32989-33000 (2017).

\section{Acknowledgements}

This work was funded by NSFC (51203079), the Natural Science Foundation of Tianjin (14JCYBJC18100) and PCSIRT (IRT1257). 


\section{Author contributions}

K.H. designed the study and wrote the paper. H.S. and D.Z. contributed in measuring and analysing the data. All authors thoroughly reviewed the manuscript. All authors read and approved the final version of this manuscript.

\section{Competing interests}

The authors declare no competing interests.

\section{Additional information}

Supplementary information The online version contains supplementary material available at https://doi.org/xxxx.

Correspondence and requests for materials should be addressed to K.H.

Reprints and permissions information is available at www.nature.com/reprints.

Publisher's note Springer Nature remains neutral with regard to jurisdictional claims in published maps and institutional affiliations. 


\section{Supplementary Files}

This is a list of supplementary files associated with this preprint. Click to download.

- Supplementaryinformation.pdf 